\title{
RADON CONCENTRATION IN CAVES AS A PROXY FOR TECTONIC ACTIVITY IN THE CANTABRIAN MOUNTAINS (SPAIN)
}

\author{
KONCENTRACIJE RADONA V JAMAH KOT KAZALNIK \\ TEKTONSKE AKTIVNOSTI V KANTABRIJSKEM GOROVJU \\ (ŠPANIJA)
}

\author{
Daniel BALLESTEROS ${ }^{1,2,}$, Sergio LLANA-FÚNEZ ${ }^{3}$ Mónica MELÉNDEZ-ASENSIO ${ }^{4}$, Ismael \\ FUENTEMERINO $^{5}$, Carlos SAINZ ${ }^{5}$, Luis QUINDÓS ${ }^{5} \&$ Irene DeFELIPE $^{6}$
}

\begin{abstract}
UDC 551.44:546.296(460)

Daniel Ballesteros, Sergio Llana-Fúnez, Mónica MeléndezAsensio, Ismael Fuente Merino, Carlos Sainz, Luis Quindós \& Irene DeFelipe: Radon concentration in caves as a proxy for tectonic activity in The Cantabrian Mountains (Spain)

Radon (Rn) constitutes a good geochemical tracer for neotectonic activity in faults since associated fracturing near the surface favours fluid escape to the atmosphere. In this contribution, we measured the Rn concentration in the air inside karst caves to constraints the recent fault activity in the Cantabrian Mountains (N Spain). Rock formations exhumed during the uplifting of the Cantabrian Mountains record a long history of fracturing, which has the potential to connect deeper sources of Rn with the surface. In this regional study, we correlate $\mathrm{Rn}$ measurements with cave survey data and geological structures using a Geographic Information Systems. Thirty-four Rn average concentration was recorded by CR-39 detectors during 8 integrated months. The method is applied to the central part of the Cantabrian Mountains that is built on sedimentary and low-grade metamorphic rocks relatively poor in U. Dominant tectonic structures and $\mathrm{Rn}$ concentration are examined in 28 cavities. The concentration of $\mathrm{Rn}$ values is higher than $0.5 \mathrm{kBq} \cdot \mathrm{m}^{-3}$ in caves developed preferably following fractures with the direction $\mathrm{N} 30^{\circ} \mathrm{W}$, being the concentration greater than $0.8 \mathrm{kBq} \cdot \mathrm{m}^{-3}$ in cavities located less
\end{abstract}

Izvleček

UDK 551.44:546.296(460)

Daniel Ballesteros, Sergio Llana-Fúnez, Mónica MeléndezAsensio, Ismael Fuente Merino, Carlos Sainz, Luis Quindós \& Irene DeFelipe: Koncentracije radona v jamah kot kazalnik tektonske aktivnosti $v$ Kantabrijskem gorovju (Španija)

Prenos radona iz globokih virov na površje velikokrat poteka vzdolž dobro prevodnih neotektonskih razpoklinskih struktur. Zato je povečana koncentracija radona na površju eden od potencialnih kazalnikov tektonske aktivnosti v nekem masivu. V raziskavi smo ugotavljali povezavo med koncentracijo radona $\mathrm{v}$ kraških jamah in tektonskimi strukturami v Kantabrijskem gorovju v severni Španiji. Zaradi tektonskega dvigovanja Kantabrijskega gorovja, so formacije močno razpokane, zato so povezave med globokimi viri radona in površjem zelo verjetne. $\mathrm{Z}$ detektorji CR-39 smo na 34 točkah izmerili povprečno koncentracijo radona v obdobju osmih mesecev. Meritve koncentracije radona so bile izvedene v 28 jamah v centralnem delu Kantabrijskega gorovja. Območje je pretežno iz sedimentnih in nizko metamorfoziranih kamnin z nizko vsebnostjo urana. Korelacijo med koncentracijo radona $\mathrm{v}$ jamah ter položajem tektonskih struktur smo določali $\mathrm{z}$ orodji geografskih informacijskih sistemov. Koncentracije radona nad $0,5 \mathrm{kBq} \cdot \mathrm{m}^{-3}$ smo izmerili $\mathrm{v}$ jamah, ki so nastale ob tektonskih strukturah v smeri sever-zahod. Med temi smo koncentracijo nad $0,8 \mathrm{kBq} \cdot \mathrm{m}^{-3}$ izmerili v jamah, ki so v bliži-

\footnotetext{
${ }^{1}$ Department of Geodynamics, c/ Campus de Fuentenueva s/n, E-18071 Granada, Spain, e-mail: ballesteros@geol.uniovi.es

${ }^{2}$ UMR 6266 IDEES, University of Rouen-Normandie/CNRS, 7 Rue Thomas Becket, FR-76821 Mont Saint-Aignan, France, e-mail: ballesteros@geol.uniovi.es

${ }^{3}$ Geocantábrica Group, Department of Geology, University of Geology, c/ Jesús Arias de Velasco s/n. E-33005 Oviedo, Spain, e-mail: llanasergio@uniovi.es

${ }^{4}$ Instituto Geológico y Minero de España. c/ Matemático Pedrayes 25, E-33005, Oviedo, Spain, e-mail: m.melendez@igme.es

${ }^{5}$ RADON Group, Department of Medical Physics, University of Cantabria. c/ Cardenal Herrera Oria s/n, E-39011 Santander, Spain, e-mails: fuentei@unican.esm, carlos.sainz@unican.es, luis.quindos@unican.es

${ }^{6}$ Geosciences Barcelona (GEO3BCN-CSIC), c/ Lluís Sole i Sabaris s/n, E-08028, Barcelona, Spain, e-mail: irene.defelipe@gmail.com

* Corresponding author
} 
than $200 \pm 50 \mathrm{~m}$ from subvertical faults with such orientation. $\mathrm{Rn}$ anomalies point to relative high connectivity along subvertical fault zones NW-trending, preserving fracture connectivity in the most recent structures in the Cantabrian Mountains. Finally, in the study area there is a low but significant radioactive hazard which is associated to fault zones in a fractured rock massif. It contrasts with other active tectonic settings where the radioactive hazard may come from fault movements.

Key words: Active fault, geoindicator, karst cave, radon. ni $(<200 \pm 50 \mathrm{~m})$ subvertikalnih prelomov. Visoke koncentracije radona kažejo na dobro razpoklinsko povezanost masiva, ki jo $\mathrm{v}$ najmlajših strukturah Kantabrijskega gorovja vzdržujejo subvertikalni prelomi v smeri sever-zahod. Študija je pokazala, da je na območju raziskave majhno, a značilno tveganje povečane radioaktivnosti v povezavi s prelomnimi in razpoklinskimi conami. V nasprotju s tem je $\mathrm{v}$ drugih tektonsko aktivnih okoljih radioaktivno tveganje povezano s premiki aktivnih prelomov.

Ključne besede: aktivni prelom, geokazalniki, kraška jama, radon.

\section{INTRODUCTION}

Three physical properties of radon $(\mathrm{Rn})$ make this element a reasonable geochemical tracer to identify active geological structures (e.g., Barbosa et al. 2015; Baskaran 2016): 1) Rn is a gas that has a relative high mobility, even through low porosity rock formations; 2) Rn is a noblre gas that does not combine with other elements, thus it is not influenced by biotic processes; and 3) the half-life of the $\mathrm{Rn}$ is short ( 3.8235 days for ${ }^{222} \mathrm{Rn}$, the most common isotope), therefore its presence is indicative of a nearby source (e.g., rocks with high Rn concentration) and/or a quick transport from the source.

The occurrence of the Rn depends on its emanation fraction linked to rocks and the permability of the bedrock. The emanation fraction is an intrinsic property of the rocks and controls the escape of Rn from the solid grains to the porous media (Sakoda et al. 2010; Lee et al. 2018). To be transported to the surface, $\mathrm{Rn}$ requires a carrier that can be either water, $\mathrm{CO}_{2}, \mathrm{CH}_{4}$ or magma, and a high permeability pathway. Thus, the deeper the source is located, the higher the permeability is required (Katsanou et al. 2010; Sciarra et al. 2015). The geometry and arrangement of fractures or discontinuities in the crust are key in order for the gas to be transported the surface. Additionally, the permeability of an intact rock increases two to ten orders of magnitude with the presence of organised fracture systems, but also by the intersection between them, particularly when the intersecting fractures are subvertical (Sibson 1992, 1996). For these reasons, Rn has been used extensively as a tracer for seismic activity of fault zones (e.g., Ghosh et al. 2011; Briestensky et al. 2014; Koike et al. 2014), detecting Rn anomalies in active faults as the San Andreas fault (see Morrow et al. 2014). However, Woith (2015) found that in continuous monitoring of Rn concentration, anomalies associated with non-tectonic origin produced similar anomalies to those associated with faults. The influence of weather, groundwater conditions and/or the lithology can be of similar magnitude to tectonic causes (Girault et al. 2012; Zarroca et al. 2012).

$\mathrm{Rn}$ can accumulate in karst caves due to their low ventilation, representing anomalies in Rn (Elío et al.
2017). Annual average Rn concentrations in karst caves ranges typically from 0.2 to $15 \mathrm{kBq} \cdot \mathrm{m}^{-3}$ (Kobal et al. 1986, 1987; Hakl et al. 1997; Vaupotič 2010; Somlai et al. 2011; Bourges et al. 2014; Nguyet et al. 2018; Smith et al. 2019), being $2.8 \mathrm{kBq} \cdot \mathrm{m}^{-3}$ the average concentration measured in 220 caves around the World (Hakl et al. 1997). However, higher concentrations have been reported, for instance: $155 \mathrm{kBq} \cdot \mathrm{m}^{-3}$ in the UK (Gunn et al. 1991), 23-168 kBq.m ${ }^{-3}$ in Spain (Dueñas et al. 1999; Lario et al. 2005; Fernandez-Cortes et al. 2009; Alvarez-Gallego et al. 2015), $4-123 \mathrm{kBq} \cdot \mathrm{m}^{-3}$ in China (Wang et al. 2019), 88 $\mathrm{kBq} \cdot \mathrm{m}^{-3}$ in Greece (Papastefanou et al. 2003), $84 \mathrm{kBq} \cdot \mathrm{m}^{-3}$ in USA (Kowalczk and Froelich 2010) and 27-54 kBq. $\mathrm{m}^{-3}$ in Slovenia (Gregorič et al. 2013).

The concentration of Rn varies over time and space one to two orders of magnitude in karst caves (Fernandez et al. 1984, 1986). Its accumulation in caves is ultimately controlled by the interaction between the cave system, the atmosphere, the groundwater system and the geological bedrock, which necessarily must include the fracture network. Thus, Rn concentration is sensitive to cave ventilation, groundwater conditions, cave sediment distribution and/or uranium content in the bedrock and karst deposits (Hakl et al. 1997). The ventilation depends on wind dynamics within the cave (exhalation or inhalation flux, stratified air), controlled by differences in temperature between the outside and inside of the cavity, atmospheric pressure oscillations the geometry of the karst cave, as well as anthropic factors (Xie et al. 2015; Dumitru et al. 2016; Pérez-López et al. 2017). In general, caves in Atlantic areas show peak concentrations of $\mathrm{Rn}$ in winter and minimum values in summer, when the ventilation is usually higher (e.g., Fernandez-Cortes et al. 2011; Lu et al. 2011). Groundwater conditions control the presence of Rn differently, being higher during humid seasons. This is caused by the role of the water as an important carrier of $\mathrm{Rn}$ and the increment of vapour condensation in porous media in bedrocks and sediments, which reduce the air-filled porosity (Fernandez-Cortes et al. 2011, 2013). This is common in winter in temperate climate re- 
gions. Recent studies revealed that sediments rich in clay can control Rn diffusion from the bedrock to the cave passages (Gillmore et al. 2002; Gregorič et al. 2013). At the same time, these sediments may constitute an additional source of $\mathrm{Rn}$, which may include $\mathrm{U}$ as a tracer (Porstendörfer 1994; Gillmore et al. 2000).

In spite of the complex microclimatic characteristics of cave systems, Rn measurements in karst caves have often been correlated with seismicity and crustal deformation, requiring the continuous monitoring of Rn concentration in cavities (Garavaglia et al. 1998; Šebela et al. 2010; Briestensky et al. 2011) as well as other gasses that may be released during tectonic activity such as $\mathrm{CO}_{2}$ (e.g., Chiodini et al. 2011; Smeraglia et al. 2016). Preliminary results of these works indicate that tectonic activity in convergent settings produce higher $\mathrm{Rn}$ anomalies, while extensional settings do not generally seem to affect the concentration of this gas, although high values in extensional setting have been also measured (Steinitz et al. 2003).

In the Cantabrian Mountains (northern Iberian Peninsula), Rn concentration have been documented in dwellings (e.g., García-Talavera et al. 2013), groundwater (González-Díez et al. 2009), karst caves (see Sainz Fernández et al. 2017) and in two regional structures, named Sabero and León faults (Fig. 1; Künze et al. 2012). Both faults are relevant from a regional geological point of view and have similar accumulated displacement $(\sim 5$ $\mathrm{km})$. The main difference between them resides in their seismicity record, as the Ventaniella fault shows an associated low magnitude clustering of earthquakes (LópezFernández et al. 2004, 2018), absent in the Sabero fault. Radon concentration in soil covering the fault resulted to be four times higher in the Sabero fault (up to 441 $\mathrm{kBq} \cdot \mathrm{m}^{-3}$ ) with respect to the Ventaniella fault (up to 106 $\mathrm{kBq} \cdot \mathrm{m}^{-3}$ ), despite the former being regarded as aseismic. Motivated by this, we carried out the measurement of Rn gas in 28 karst caves with the aim of identifying the regional fracture system that facilitates the current ascent of Rn through the upper crust. For this purpose, we combine in a Geographic Information System (GIS) three essential pieces of information: Rn measures, speleological cave survey data and structural data in geological maps.

\section{GEOLOGICAL SETTING}

\section{TECTONIC EVOLUTION OF THE CRUST}

The Cantabrian Mountains and the Pyrenees formed in the Alpine tectonic cycle during the Paleogene collision between African and European tectonic plates, when the plate boundary was located to the north of the Iberian plate (Fig. 1A) (e.g., Srivastava et al. 1990; Teixell et al. 2018; DeFelipe et al. 2019). Specifically, the Cantabrian Mountains were exhumed by the reactivation of Variscan faults E-W oriented, and therefore subperpendicular to the main N-S direction of compression of the Alpine orogeny (Alonso et al. 1996). Fig. 1B shows the main structures of the west-central Cantabrian Mountains, highlighting the Alpine faults over previous structures. Most of these existing structures affecting the alpine basement formed during the Variscan Orogeny, mostly Carboniferous in age in the study area (Pérez-Estaún et al. 1991), and during extensional events from the late Permian to Cretaceous, which led to thick sedimentary basins such as the Basque-Cantabrian basin or the offshore Asturian basin (e.g., Tugend et al. 2015; DeFelipe et al. 2017, 2018, Cadenas et al. 2018).

The exhumation of the Cantabrian Mountains during the Alpine convergence implied a huge deformation of the crust. The main alpine structure corresponds to a Svergent thrust system dipping gently to the $\mathrm{N}$ that uplifts the Cantabrian Mountains over the Duero basin (Fig. 1B) (Alonso et al. 1996; Gallastegui et al. 2016; Acevedo et al. 2019). The major period of exhumation took place in the Eocene and the Oligocene, producing the exhumation of a minimum of 1.7-3 km of rocks (Alonso et al. 1996; Martín-González et al. 2011; Fillon et al. 2016). The amount of Alpine shortening has been established in $96-98 \mathrm{~km}$ in the eastern Cantabrian Mountains (Pedreira et al. 2015; Gallastegui 2016). In terms of the amount of finite shortening and the dominant style of structures that accommodate deformation, two crustal segments in the western Cantabrian Mountains have been differentiated: an Asturian segment to the $\mathrm{E}$, dominated by frontal or longitudinal thrusts; and a Galician segment to the W, characterised by conjugate strike-slip faulting (Llana-Fúnez \& LópezFernández 2015). Both crustal segments show different relief evolution and crustal seismicity in agreement with the geometry of the dominant type of structures.

The main structures in the Cantabrian Mountains that play a role in the current crustal architecture are (1) reverse faults or thrusts and, (2) strike-slip faults. The main reverse faults described in the literature are E-W oriented, longitudinal to the orogenic belt, and are named as Llanera, Cabuérniga, Sabero and León (Fig. 1) (Alonso et al. 1996). The Llanera and Cabuérniga faults formed 
originally as normal faults in the Mesozoic and were overprinted during the Alpine Orogeny; while the Sabero and León faults are Variscan thrusts that were reactivated during the Alpine convergence (Alonso et al. 1996). The other type of structures that accommodate N-S shortening are strike-slip faults (Fig. 1B). One of these structures, the As Pontes fault, is a NW dextral strike-slip structure that uplifted the Xistral Range from the Oligocene to the Miocene (Grobe et al. 2014). Similar strike-slip faults formed in the Asturian segment, for instance the Ventaniella fault (Julivert 1967; Tavani 2012; Fernández-Viejo et al. 2014), a dextral strike-slip structure with an offset of $\sim 5 \mathrm{~km}$ (Fig. 1B). Currently, low-magnitude seismic activity is associated to the Ventaniella fault (LópezFernández et al. 2018) that elevated an erosional flat surface along the Cantabrian coast (López-Fernández et al. 2020). Faults with similar orientation are significantly more abundant to the $\mathrm{E}$ of the Ventaniella fault (Fig. 1B). Northwesterly faults constitute the boundaries of minor Permian sedimentary basins (Lepvrier and MartínezGarcía 1990) while northeasterly faults coincide with the structural orientation of an aborted rift branch (Arche \& López-Gómez 1996; Cadenas \& Fernández-Viejo 2017).
In general, karst caves in the Asturian segment show a strong structural control since they are developed in highly fractured massifs where cave conduits usually follow bedding and up to seven families of joints, as well as their mutual intersections (Ballesteros et al. 2014, 2015a). The arrangement of the karst cave segments depict the structural features within the basement but develop more strongly along those fractures with higher connectivity for aqueous fluids dissolving the rock.

\section{RN CONCENTRATIONS IN KARST CAVES}

More than $2 \mathrm{~km}$ of Paleozoic basement rocks involved in the Alpine uplift of the Cantabrian Mountains are limestones, which are Cambrian, Devonian or Carboniferous in age. All of these rock formations are karstified since at least the Pliocene (e.g., Ballesteros et al. 2019). Recent systematic studies of Rn concentration in dwellings in NW of Spain, within the study area, indicate relative local high concentrations of $\mathrm{Rn}\left(>0.3 \mathrm{kBq} \cdot \mathrm{m}^{-3}\right)$ that cannot be directly related to the lithology exposed at the surface (García-Talavera et al. 2013; Sainz Fernández et al. 2017). Recent studies in tourist karst caves in the Cantabrian Mountains measured frequently average concentrations

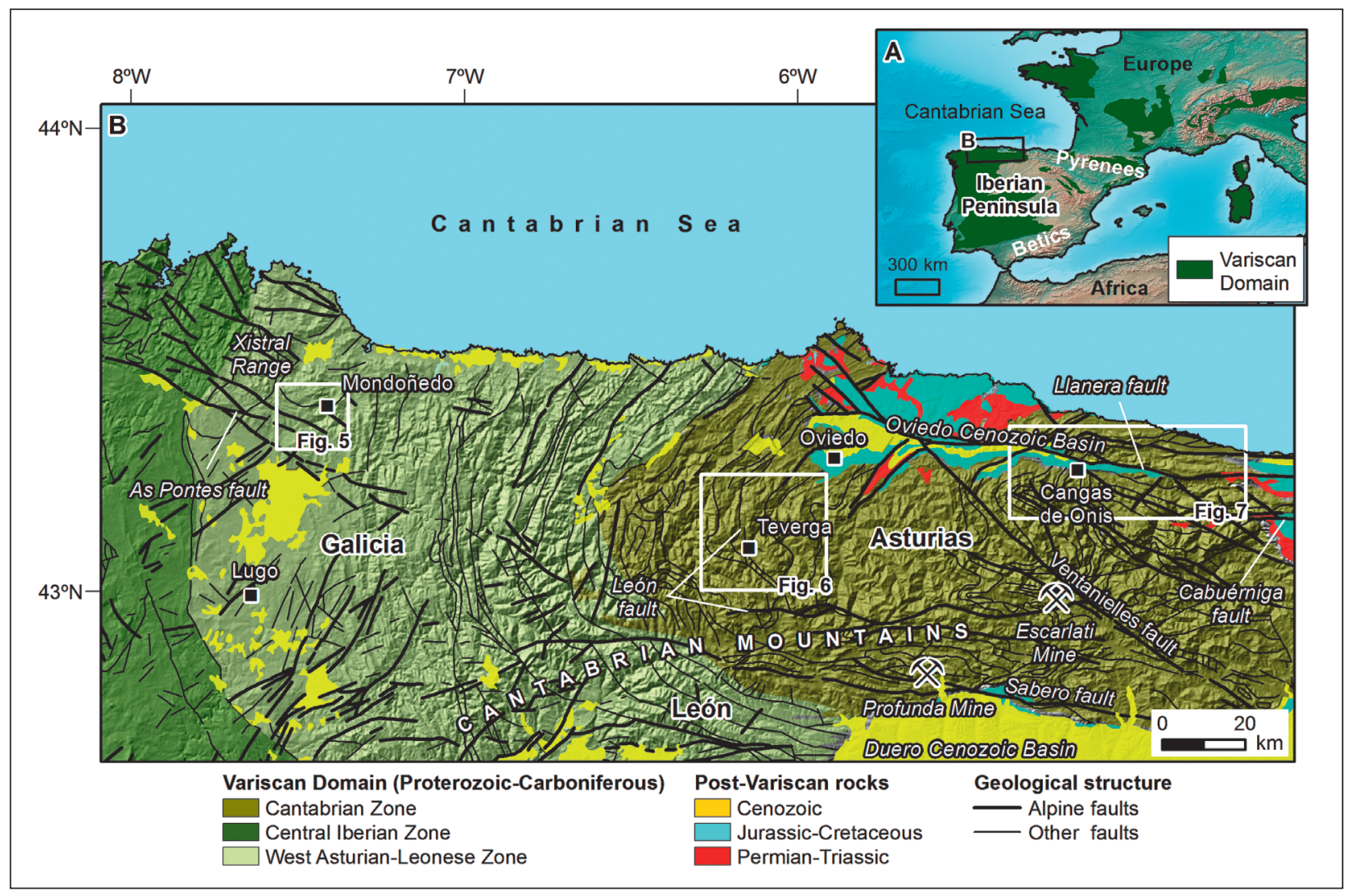

Fig. 1: (A) Location of the Cantabrian Mountains in the N of the Iberian Peninsula. (B) Synthetic geological map of the Eastern and central Cantabrian Mountains. Geology was extracted from the Spanish Geological Survey continuous geological maps (Rodríguez Fernández et al. 2015). The seismic events up to 4.1 moment magnitude were recorded between 1984 and 2014 by the Spanish Geological Survey (Instituto Geográfico Nacional, www.ign.es). 
of $0.1-1.5 \mathrm{kBq} \cdot \mathrm{m}^{-3}$ during annual campaigns, although through continuous monitoring natural peaks are up to $7.1 \mathrm{kBq} \cdot \mathrm{m}^{-3}$, and artificial peaks to $15.9 \mathrm{kBq} \cdot \mathrm{m}^{-3}$ due to the anthropic closure of the cavities (Hoyos et al. 1998; Poncela et al. 2004; Lario et al. 2005; Sainz et al. 2007). The presence of $\mathrm{Rn}$ in groundwater was also recognized as significant, generally related to thermal springs and spas since González-Díez et al. (2009) reported Rn concentrations in groundwater up to $0.8 \mathrm{kBq} \cdot \mathrm{m}^{-3}$, without a clear relationship with the lithology or tectonic structure in the bedrock exposed at the surface.

\section{METHODS AND STUDIED CAVES}

The work method includes: (1) the measurement of $\mathrm{Rn}$ concentration in karst caves air; (2) the analyses of the main directions of the caves and their relation to tectonic and other geological structures, and (3) the projection of the cave topography on a geographical information system (GIS) in order to establish relationships between Rn concentration, cave direction and the geological tectonic structure.

Twenty-eight caves were selected for this study in the Cantabrian Mountains, divided into three areas: Mondoñedo, Teverga and Cangas de Onís (Fig. 1B). The areas were selected according to the presence of key regional structures. The first area is located in the Galician segment of the Cantabrian Mountains and comprises four caves to the SE of Mondoñedo (Fig. 1B). These cavities were developed in metamorphosed Cambrian limestone affected by minor faults with a NW-SE direction. The cavities are located at the southeastern lateral termination of the As Pontes fault (Santanach et al. 2005). The Teverga area is located to the SW of Oviedo (Asturias) and includes five cavities developed in Carboniferous limestone, some of them nearby the León fault (Fernández et al. 2018). The Cangas de Onís area is located to the E of the Oviedo Cenozoic Basin, where twenty-two caves were studied. The basin shows an elongated shape in the E-W direction, controlled by the Llanera fault to the $\mathrm{N}$, which elevates the northern block. The Llanera fault is cut across by the Ventaniella fault with a northwesterly trend (Alonso et al. 1996; Pulgar et al. 1999).

$\mathrm{Rn}$ concentration was measured using CR-39 detectors following Sainz et al. (2007), Somlai et al. (2011), Dumitru et al. (2016) and Smith et al. (2019). These detectors were fastened under the cap of a cylindrical polypropylene container that prevents $\mathrm{Rn}$ decay products and ${ }^{220} \mathrm{Rn}$ from entering. One detector was placed inside each cavity, except in the Rei Cintolo cave (two detectors), Güerta cave (five detectors) and Vegalonga cave (two detectors) because they are kilometric caves. The location of the detector within the cavity followed three criteria: $\sim 5 \mathrm{~m}$ from the cave entrance, cave passages should have little or absent clay deposits, relative dry walls and lack evidences of water condensations such as water drips or moonmilk.

The detectors were recording from winter to autumn 2016, covering dry and wet periods. The accumulated radiation by alpha particles from ${ }^{222} \mathrm{Rn}$ was determined by counting the tracks produced in track-etched detectors (Poncela et al. 2004; Sainz et al. 2007) in the Laboratory of Environmental Radioactivity of the University of Cantabria (Spain), accredited by the Spanish National Entity (ENAC, ISO/IEC 17025). The error of the measurements was 6-9\% and the limit of detection was 6 $\mathrm{Bq} \cdot \mathrm{m}^{-3}$. Rn concentration was calculated from the ratio of the accumulated radiation by the exposition time.

The main directions for the twenty-eight caves were calculated using rose-diagrams, extracting lengths and orientation of galleries from cave surveys. The speleological groups GE Polifemo, GES Montañeiros Celtas, SIS CE Terrassa, GE Diañu Burlón, GE Gorfolí, SEB Escar and CADE-FESPA provided the original survey data for twelve cavities. Another eight caves were surveyed using the DistoX laser distanciometer and restored the survey data of eight cavities (Favre 1978; L'Esperteyu Cavernícola-Espéleo Club 1987; Puch 1998) following Ballesteros et al. (2014).

The orientation of cave entrances and their conduits extracted from the geological map were projected in a rose diagram to establish the link between $\mathrm{Rn}$ concentrations, cave main directions and the geological structure. Cave speleological surveys and $\mathrm{Rn}$ concentration values were later introduced in ArcGIS 10, together with the digital and continuous geological map GEODE carried out by the Geological Survey of Spain (compiled by González Menéndez et al. 2008 in the West-Asturian Leonese Zone and by Merino-Tomé et al. 2013 in the Cantabrian Zone). The spatial analysis in GIS allowed us to establish the correlation between concentration values and the orientation of major dominant discontinuities for each measurement locality, and to calculate the distance between each cave to the nearest fault. The relationship of these parameters was inferred using polynomical equations of second degree. 
Tab. 1: Rn concentrations in cave air (measured from winter to autumn 2016), cave geometry (length, vertical range, verticality index and main direction), relative cave ventilation and the distance between the cavities and the northwesterly trending faults (the distance is zero if the faults intercept the cave). The vertical index is the quotient between the vertical range and the cave length (Piccini 2011). Rn concentration values in Arenas and Les Escobes caves are below the detection limit. Determination of relative cave ventilation is qualitative and based on the number of entrances, vertical range of the cave and between entrances, and air flux (mainly inhalant or exhalant during measuring, wind velocity).

\begin{tabular}{|c|c|c|c|c|c|c|c|c|}
\hline \multirow[b]{2}{*}{ Study cave } & \multirow{2}{*}{$\begin{array}{c}\text { Rn concentra- } \\
\text { tion } \\
\left(\mathrm{Bq} \cdot \mathrm{m}^{-3}\right)\end{array}$} & \multicolumn{5}{|c|}{ Cave geometry } & \multirow{2}{*}{$\begin{array}{c}\text { Relative } \\
\text { cave ven- } \\
\text { tilation }\end{array}$} & \multirow{2}{*}{$\begin{array}{l}\text { Distance } \\
\text { (m) to faults } \\
\text { with N-S } \\
\text { and NE-SW } \\
\text { trending }\end{array}$} \\
\hline & & $\begin{array}{l}\text { Length } \\
\text { (m) }\end{array}$ & $\begin{array}{l}\text { Vertical } \\
\text { range } \\
\text { (m) }\end{array}$ & $\begin{array}{l}\text { Verticality } \\
\text { index }\end{array}$ & $\begin{array}{c}\text { Main } \\
\text { direction } \\
(\underline{o})\end{array}$ & $\begin{array}{c}\text { Number of } \\
\text { known } \\
\text { entrances }\end{array}$ & & \\
\hline Alda & $1155 \pm 82$ & 394 & 28 & 0.07 & 175 & 1 & Low & 350 \\
\hline Arangas & $156 \pm 17$ & 42 & 4 & 0.10 & 77 & 1 & Low & 300 \\
\hline Arenas & $<21$ & 27 & 4 & 0.15 & 104 & 3 & High & 300 \\
\hline Berdayes & $825 \pm 58$ & 288 & 15 & 0.05 & 25 & 1 & Low & 50 \\
\hline Canes & $1344 \pm 83$ & 837 & 71 & 0.08 & 163 & 1 & Low & 80 \\
\hline Carmona & $1709 \pm 118$ & 15 & 14 & 0.93 & 34 & 1 & Low & 100 \\
\hline Collía & $3816 \pm 262$ & 268 & 6 & 0.02 & 5 & 1 & Low & 1050 \\
\hline Cuerres & $315 \pm 25$ & 107 & 22 & 0.21 & 105 & 1 & High & 1800 \\
\hline Cave $\mathrm{X}$ & $882 \pm 62$ & 1810 & 60 & 0.03 & 60 & 1 & Low & 300 \\
\hline Güerta 1 (N-S gallery) & $1539 \pm 105$ & \multirow{5}{*}{$>23350$} & \multirow{5}{*}{281} & \multirow{5}{*}{0.01} & \multirow{5}{*}{165} & \multirow{5}{*}{2} & \multirow{5}{*}{ High } & \multirow{5}{*}{0} \\
\hline Güerta 2 (E-W gallery) & $1109 \pm 78$ & & & & & & & \\
\hline Güerta 3 (N-S gallery) & $1610 \pm 110$ & & & & & & & \\
\hline Güerta 4 (N-S gallery) & $1616 \pm 112$ & & & & & & & \\
\hline Güerta 5 (N-S gallery) & $1628 \pm 113$ & & & & & & & \\
\hline Güeyos del Riu & $1022 \pm 70$ & 10 & 2 & 0.20 & 160 & 1 & Low & 50 \\
\hline La Peruyal & $2429 \pm 167$ & 294 & 33 & 0.11 & 95 & 1 & Low & 40 \\
\hline La Porquera & $155 \pm 14$ & 365 & 15 & 0.04 & 125 & 1 & Low & 800 \\
\hline La Trapa & $397 \pm 28$ & $>1000$ & 100 & 0.10 & 35 & 1 & Low & 250 \\
\hline Les Cámares & $320 \pm 26$ & 89 & 8 & 0.09 & 135 & 1 & Low & 450 \\
\hline Les Escobes & $<13$ & 409 & 15 & 0.04 & 95 & 1 & High & 300 \\
\hline Les Paraes & $239 \pm 20$ & 16 & 7 & 0.44 & 145 & 1 & Low & 850 \\
\hline Lobos & $161 \pm 14$ & 170 & 22 & 0.13 & 35 & 1 & Low & 550 \\
\hline Los Covazones & $49 \pm 9$ & 4219 & 171 & 0.04 & 45 & 1 & High & 860 \\
\hline Marabio & $27 \pm 6$ & 10 & 1 & 0.10 & 90 & 1 & High & 1400 \\
\hline Obar & $2636 \pm 181$ & 3563 & 197 & 0.06 & 74 & 1 & Low & 0 \\
\hline Osu & $87 \pm 11$ & 3600 & 220 & 0.06 & 120 & 3 & High & 500 \\
\hline Peches & $1741 \pm 122$ & 32 & 12 & 0.38 & 71 & 1 & Low & 150 \\
\hline Pedraces & $332 \pm 27$ & 5 & 0 & 0.00 & 85 & 1 & Low & 400 \\
\hline Rei Cintolo 1 & $1830 \pm 126$ & \multirow{2}{*}{$>4000$} & \multirow{2}{*}{100} & \multirow{2}{*}{0.03} & \multirow{2}{*}{60} & \multirow{2}{*}{1} & \multirow{2}{*}{ Low } & \multirow{2}{*}{150} \\
\hline Rei Cintolo 2 & $1914 \pm 131$ & & & & & & & \\
\hline Santos & $1832 \pm 125$ & 40 & 16 & 0.40 & 150 & 1 & Low & 350 \\
\hline Vegalonga 1 & $221 \pm 21$ & \multirow{2}{*}{5900} & \multirow{2}{*}{212} & \multirow{2}{*}{0.04} & \multirow{2}{*}{45} & \multirow{2}{*}{2} & \multirow{2}{*}{ High } & \multirow{2}{*}{600} \\
\hline Vegalonga 2 & $46 \pm 10$ & & & & & & & \\
\hline Vistulaz & $136 \pm 12$ & 3050 & 85 & 0.03 & 30 & 1 & High & 1600 \\
\hline
\end{tabular}




\section{RESULTS}

The main characteristics of the selected twenty-eight caves and the results of average Rn concentration over the length of the study are listed in Tab. 1. This table shows $\mathrm{Rn}$ concentrations in sixteen caves to be lower than $500 \mathrm{~Bq} \cdot \mathrm{m}^{-3}$, the air of ten cavities shows values between $825-1914 \mathrm{~Bq} \cdot \mathrm{m}^{-3}$, and in three caves the Rn content exceeds $2400 \mathrm{~Bq} \cdot \mathrm{m}^{-3}$. Concentrations below $13-21 \mathrm{~Bq} \cdot \mathrm{m}$ ${ }^{3}$, the resolution limit of the technique, were found in two caves.

The general ventilation in twenty caves is relatively low since the caves are mainly formed by horizontal galleries, their vertical range is less than $100 \mathrm{~m}$, cave streams are absent, and the cavities have only one reported entrance. In relative terms, these caves represent natural traps with relative poor ventilation. In contrast, there are eight caves in which the ventilation is relatively high. In four of them, the Les Escobes, Covazones and Marabio caves, the air flow is mainly towards the inside of the cavity, thus tending to reduce the concentration of $\mathrm{Rn}$ gas. The entrances of the other four caves, Güerta, Osu, Veigalonga, Vistulaz caves, are usually exhalant, with air flow velocities that can exceed $4 \mathrm{~m} \cdot \mathrm{s}^{-1}$. Accordding to these results, the cave ventilation can not explain the Rn measures carried out in caves. In all limestone massifs, whether Cambrian in the Mondoñedo area or Carboniferous in age in the remaining areas, the $\mathrm{U}$ content is almost irrelevant (González-Díez et al. 2009) and the emanation power of the hosting rocks is relatively low,

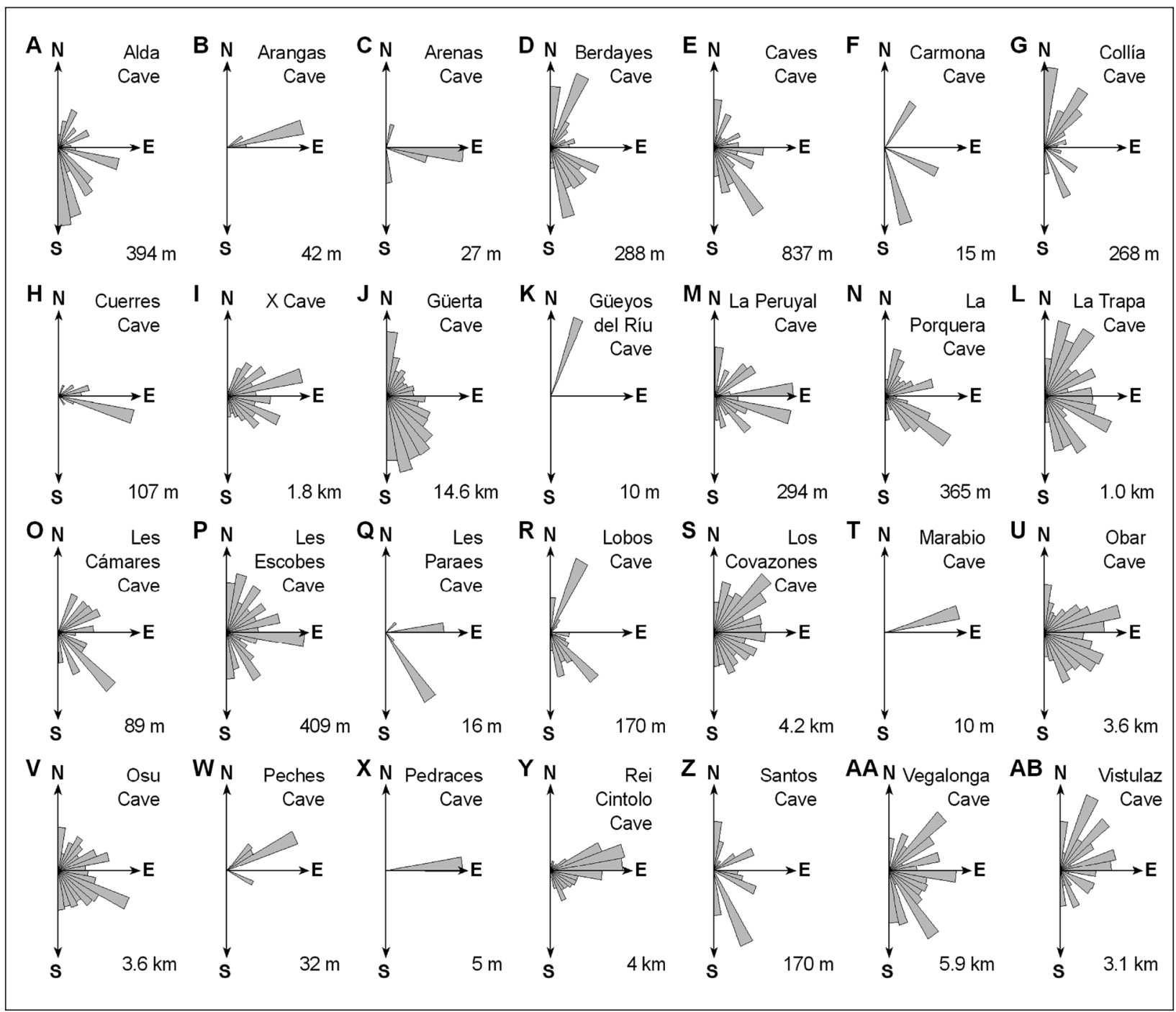

Fig. 2: Rose diagrams for each cave segment showing the main direction of cavity segments (see Tab. 1). The full length of the caves is also indicated. 
estimated in $70.1 \pm 2.0 \mathrm{~Bq} \cdot \mathrm{m}^{-3}$ (García-Talavera et al. 2013). The contribution to $\mathrm{Rn}$ concentration in cavities by the host rock can be regarded as relatively low.

The studied caves range in length from $5 \mathrm{~m}$ to $23 \mathrm{~km}$ of conduits, being the vertical range up to $281 \mathrm{~m}$ (Tab. 1). The orientation of cavity segments in a rose diagram shows their main orientations to be uniformly distributed from $\mathrm{N}^{\circ}-180^{\circ} \mathrm{E}$ (Fig. 2). In general, Rn levels are higher than $500 \mathrm{~Bq} \cdot \mathrm{m}^{-3}$ in caves orientated following the directions $\mathrm{N} 150^{\circ}-180^{\circ} \mathrm{E}$, although an increment in this gas is also detected in caves with the $\mathrm{N}^{\circ}-30^{\circ} \mathrm{E}$ main direction (Fig. 3). The exceptions to this are the caves of La Peruyal, Obar, Peches, Rei Cintolo and Cave X, with $\mathrm{Rn}$ concentrations from 882 to $2636 \mathrm{~Bq} \cdot \mathrm{m}^{-3}$. Such high values are related to the presence of nearby faults, as described in the following paragraph. Besides, the five detectors installed in the Güerta Cave indicate that the $\mathrm{Rn}$ content is 1.5 times higher in galleries with N-S direction $\left(1539-1628 \mathrm{~Bq} \cdot \mathrm{m}^{-3}\right)$ than in conduits with a W-E direction $\left(1109 \pm 78 \mathrm{~Bq} \cdot \mathrm{m}^{-3}\right)$.

The $\mathrm{Rn}$ concentration data shows a dependence on the distance between the caves and faults with NW-SE orientation, except the case of Güerta Cave that intercepts a N-S trending fault (Fig. 4) (Llana-Fúnez and Ballesteros 2020). The concentration is greater than 825 $\mathrm{Bq} \cdot \mathrm{m}^{-3}$ in cavities located less than $100 \pm 50 \mathrm{~m}$ from a fault, and it is lower than $332 \mathrm{~Bq} \cdot \mathrm{m}^{-3}$ in caves more than ca. $400 \mathrm{~m}$ away from a cartographic fault. In the latter group of cavities, the Rn concentration approaches the regional background values in the study area. Despite the general trend described, the Collía Cave presents the largest measured $\mathrm{Rn}$ concentration $\left(3816 \mathrm{~Bq} \cdot \mathrm{m}^{-3}\right)$ in spite of its location $1050 \mathrm{~m}$ away from a NW-SE orientated fault.
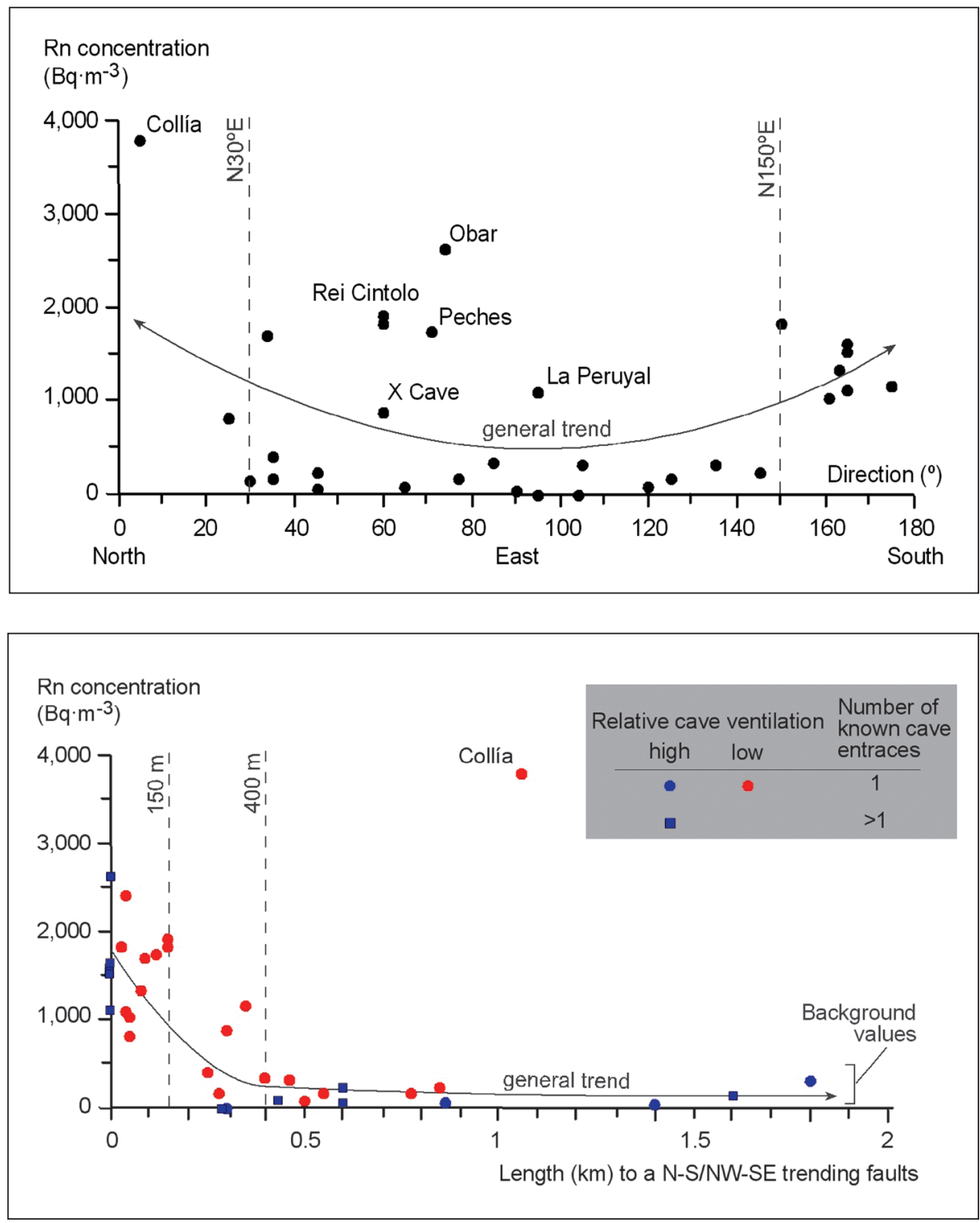

Fig. 3: Rn concentration with respect to the dominant orientation for each cave (data detailed in Tab 1).
Fig. 4: $R$ n concentration in cave air with respect to distance to NE-SW trending faults ( $N-S$ directions in the case of the Güerta Cave). Further details in Tab. 1. 


\section{DISCUSSION}

\section{GEOLOGICAL INTERPRETATION OF THE RN ANOMALIES}

The concentration of $\mathrm{Rn}$ in air within karst caves in the cavities selected shows a clear geometric relation to the orientation of cartographic faults. In the Mondoñedo area (Fig. 5), the high values of Rn concentration (1.8-1.9 $\mathrm{kBq} \cdot \mathrm{m}^{-3}$ ) identified in the Rei Cintolo and Santos caves are related to northwesterly faults. In fact, the small fractures depicted in Fig. 5 represent the lateral termination of the As Pontes fault, which is associated with the rise of the Xistral Range in northern Galicia (Grobe et al. 2014).

In the Teverga area (Fig. 6), the Güerta Cave (>23.3 $\mathrm{km}$ long), following partly the León fault, shows the highest $\mathrm{Rn}$ concentrations in the area $\left(1.1-1.6 \mathrm{kBq} \cdot \mathrm{m}^{-3}\right)$ despite the relatively high ventilation in the cave. The León fault formed during the Variscan Orogeny, but parts of this major structure were likely reactivated during the Alpine Orogeny (Alonso et al. 2007, 2009; Fernández et al. 2018). The high $\mathrm{Rn}$ values associated with this structure indicate that the fault zone remains an effective pathway to the ascent of fluids through the crust.

The major fault in the Cangas de Onís area is the Llanera fault, trending W-E (Fig. 7) (Alonso et al. 1996). In general, the caves located near this fault have low $\mathrm{Rn}$ concentration, with the exception of the Gueyos del Río and Carmona caves with 1.0-1.7 kBq.m ${ }^{-3}$. Our results show that the highest concentrations of Rn, above $1.1 \mathrm{kBq} \cdot \mathrm{m}^{-3}$, in the Alda, Canes, Carmona, Colía, Obar, Peches, and Peruyal caves are associated with minor faults trending NW, very likely overprinting the Llanera fault system. The high values recorded in the Alda Cave $\left(1.1 \mathrm{kBq} \cdot \mathrm{m}^{-3}\right)$ can be related to the nearby $\mathrm{Cu}$ ore depos-

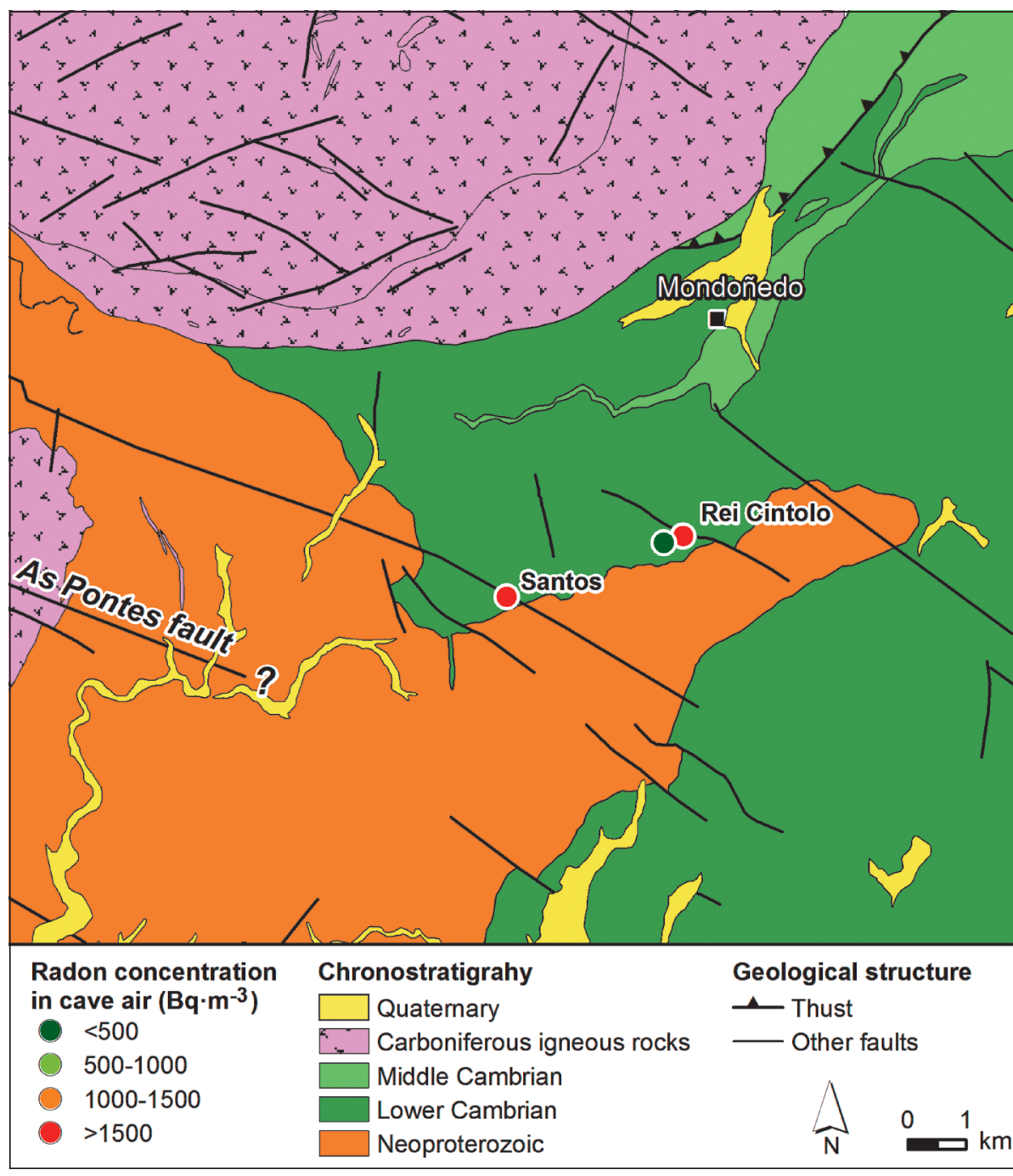

Fig. 5: Geological map of the Mondoñedo area (geology from González Menéndez et al. 2008). The location of $R n$ analyses in the three caves studied is indicated with dots, coloured according to concentration. 
its (Rodríguez-Terente et al. 2006), while the concentrations of $2.6 \mathrm{kBq} \cdot \mathrm{m}^{-3}$ in Obar cave-spring may be related to thermal springs (Ballesteros et al. 2015b). The highest $\mathrm{Rn}$ concentrations in the area were measured in the Collía Cave with $3.8 \mathrm{kBq} \cdot \mathrm{m}^{-3}$, located $3.6 \mathrm{~km}$ away from a cartographic tectonic structure. However, this cave is located in the lateral prolongation of the trace of a northwesterly fault, thus the Rn anomaly may suggest that the fracture system extends laterally beyond the cartographic structure as shown in geological maps (Fig. 7).

The correlation between $\mathrm{Rn}$ concentration and faults oriented NW-SE indicates that the permeability at depth for Rn flow in these fault systems is higher than in other fault systems. These structures overprint all earlier structures, as evidenced in geological maps (e.g., Alonso et al. 1996). For these structures to remain relatively open, and in the absence of criteria evidencing current tectonic activity, no sealing has taken place since the last tectonic event. According to the current location of the plate boundary in the Iberian Peninsula, in the $S$ of the peninsula, no tectonic activity is expected in these set of structures since it migrated in the Miocene from $\mathrm{N}$ to $\mathrm{S}$ (Teixell et al. 2018). However, these set of fractures remain an effective pathway communicating a source of $\mathrm{Rn}$ at depth with the surface. This agrees with the reported presence of Rn anomalies in aseismic scenarios (Ghosh et al. 2011; Woith 2015). It also suggests that reported $\mathrm{Rn}$ anomalies in dwellings in the study area may be related to the presence of similar structures oozing $\mathrm{Rn}$ to near surface geological formations, which can be either recent sediments or soils covering tectonically fractured bedrock.

\section{POTENTIAL RN SOURCES}

Despite of the emanation of $\mathrm{Rn}$ from the surface exposed rocks is minoritary, their contribution should be evalu-

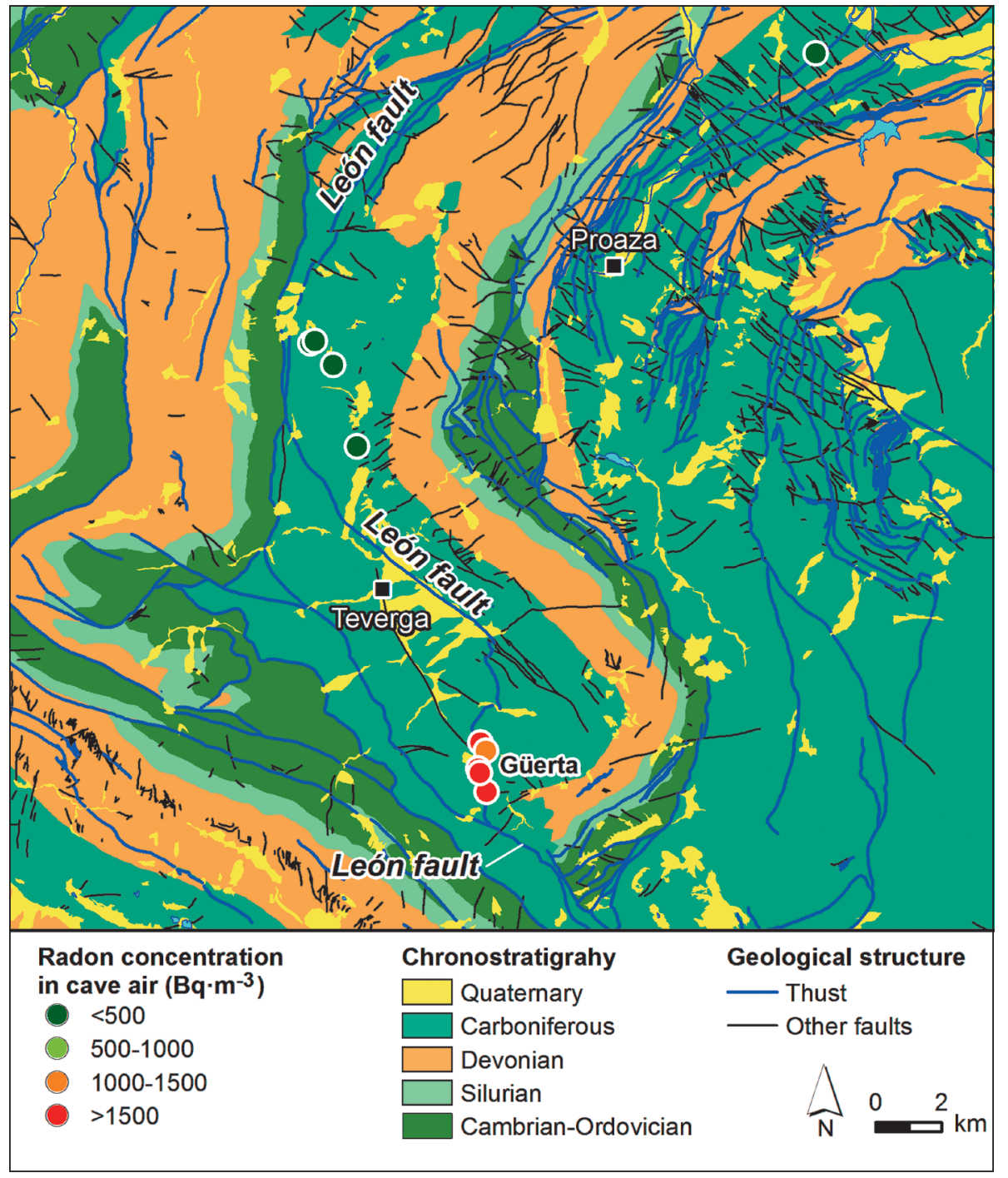

Fig. 6: Geological map of the Teverga area (geology from MerinoTomé et al. 2013). Based on geometric criteria, Variscan thrusts are shown in blue, while later fractures (very likely Alpine in age) are indicated in black. The trace of the León fault is according to Alonso et al. (2009). The location of nine analysis spots for Rn measurements in four caves are indicated with dots, coloured according to concentration (details in Tab. 1). 
ated. The specific mineral sources for Rn gas in the study area are yet unclear since the presence of igneous rocks and uranium-rich minerals in the study areas is generally low (Corretge \& Suarez 1990), in fact, none of them associated to the caves studied. Many porphyritic subvolcanic and diabasic intrusions with associated hydrothermal systems were originated in the study area following northwesterly faults (Suárez et al. 1993, 1999; FernándezSuárez et al. 1998; Gallastegui et al. 2001; Ballesteros et al. 2011). The few plutonic rocks reported in the Cantabrian Mountains have relatively low uranium, between 0.2 and $8 \mathrm{ppm}$, reaching up to $11.1 \mathrm{ppm}$ in acid rocks (Cepedal et al. 2013; Martínez-Abad et al. 2015; and unpublished data courtesy of the Petrogenesis Group of the University of Oviedo).

Northwesterly faults are in most cases polyphasic and polyorogenic in the study areas, particularly those of large entity. Close to the coast, faults with such orientation bound small Permian sedimentary basins (Martínez-García et al. 1991), and to the E of the study area, towards the Vasco-Cantabrian basin, Espina et al. (1994) reported a similar relation to Permian sedimentary rocks. In either case, the faults formed as normal extensional faults. There are two separate sets of intrusions reported in the $\mathrm{W}$ of the Asturian segment: at 285 Ma porphyritic subvolcanic intrusives, with an associated hydrothermal system, and at $255 \mathrm{Ma}$ a generation of diabasic dykes that also have an associated hydrothermal system (Martín-Iz- ard et al. 2000). Structures with NW orientation have significant ore deposits associated with hydrothermal fluids, the ages of the majority of the intrusions and associated ore bodies yield Permian ages (Martín-Izard et al. 2000; Martínez-García et al. 2004).

Overall, Permian normal faults have been interpreted to form in relation to an aborted rift branch from the Tethys (Arche \& López-Gómez 1996). To the E of the Asturias segment, there are several ore bodies that have been associated with Permian hydrothermal systems (Martínez-García et al. 2004). In the Escarlati deposit (Fig. 1), veins rich in $\mathrm{Sb}-\mathrm{Hg}$ found with a northwesterly orientation, are interpreted in relation to an $\mathrm{N}-\mathrm{S}$ shortening and have also been related to Permian hydrothermalism (Martín-Izard et al. 2009). There is one documented ore deposit with uranium minerals exposed at the surface: the Profunda Mine (Fig. 1). This deposit is characterised by $\mathrm{Cu}-\mathrm{Ni}-\mathrm{Co}-\mathrm{U}-\mathrm{As}-\mathrm{S}$ mineralisations (Paniagua et al. 1987). Although there are no reported cartographic northwesterly faults in relation to the Profunda Mine, mineralizing fluids precipitated along veins oriented following NW-SE. Yet, there is no indication of any other hydrothermally formed deposit of regional occurrence showing similar mineralogy and a potential candidate for the source of $\mathrm{Rn}$ gas at each of the caves studied. This fact supports that the Rn sources are related to the depth crust, connected to the topographic surface via fault zones.

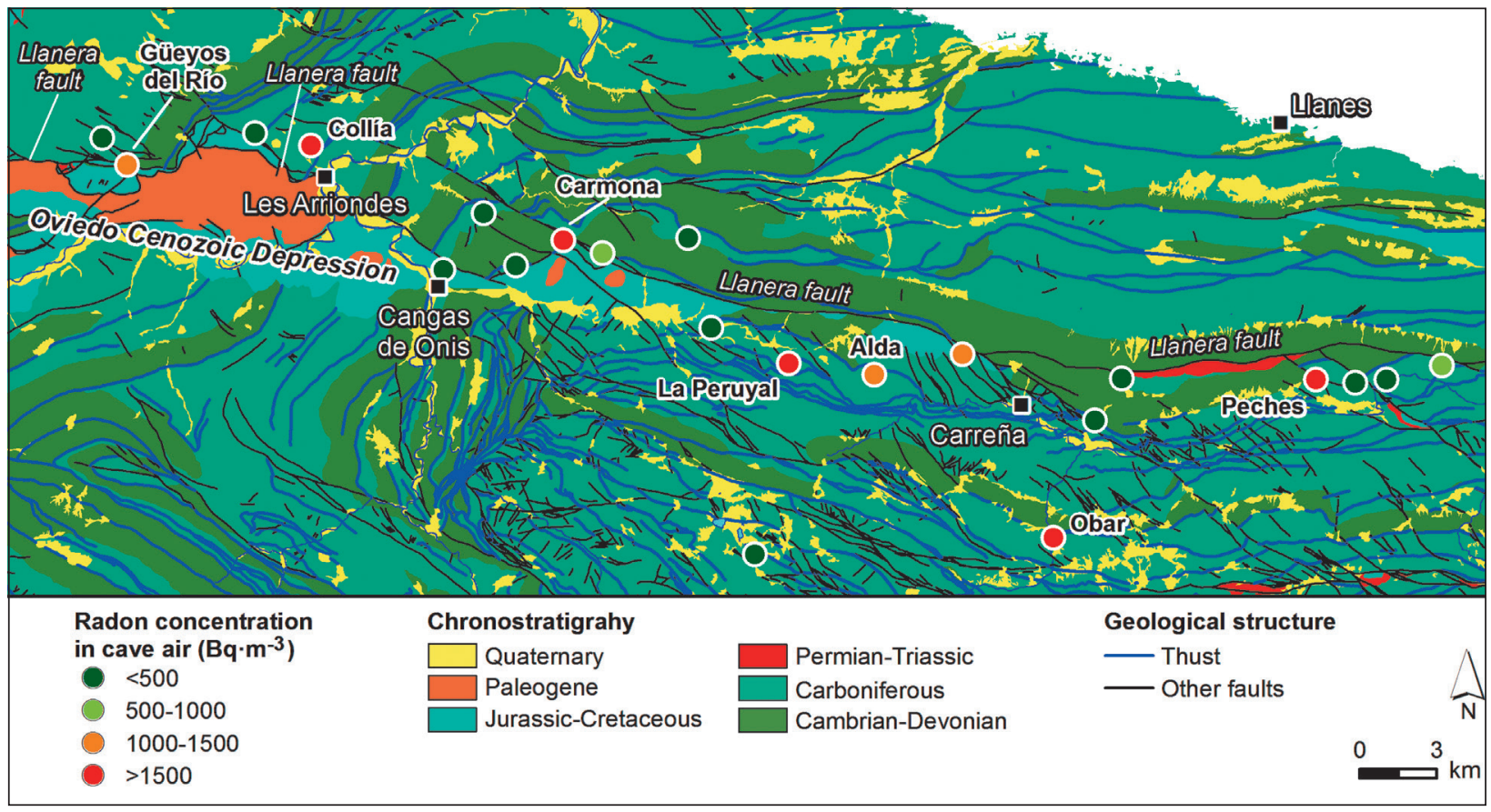

Fig. 7: Geological map of the Cangas de Onís area (geological map based in the compilation by Merino-Tomé et al. 2013). The trace of the Llanera fault is highlighted. The location of Rn concentrations in 22 caves are indicated and colour coded according to concentration (details in Tab. 1). 


\section{CONCLUSIONS}

We present thirty-four measurements of Rn concentration in air in twenty-eight karst caves from the Cantabrian Mountains. We show that cavity conduits parallel to NWSE trending subvertical faults have higher content in $\mathrm{Rn}$ $\left(>0.5 \mathrm{kBq} \cdot \mathrm{m}^{-3}\right)$ than caves more than $100 \pm 50 \mathrm{~m}$ away from faults from that particular system. Consequently, the permeability for the NW-SE trending fault is higher than other faults systems present, indicating that the northwesterly structures remain relatively open. This suggests that NWSE trending faults are related to the last tectonic event in the western and central part of the Cantabrian Mountains, as they often overprint earlier Alpine structures.

The dataset presented in this contribution provides a robust correlation among $\mathrm{Rn}$ concentration measurements, cave survey data (length, orientation and vertical range) and fault orientation data. The methodology was applied successfully in a region with Atlantic climate, with minor intraplate seismicity but a very complex tectonic history due to the presence of structures formed and overprinted by the superposition of two orogenies, Variscan and Alpine, separated by several extensional events during the Permian and Mesozoic. Despite the intrinsic tectonic complexity, the results of this work support the use of $\mathrm{Rn}$ in karst caves as an indicator of fault activity as they help identifying those with higher permeability.

\section{ACKNOWLEDGMENT}

This work is a contribution of the GEOCANTABRICA research group at the University of Oviedo, funded by a grant (GRUPIN14-044) from the Asturian Regional Government (Spain) and FEDER funds. We are greatly indebted to the Las Ubiñas-La Mesa Natural Park for provided facilities. We thank Prof. M. Jiménez-Sánchez for her support and A. Álvarez-Vena for his help during fieldwork, and to the speleological teams (GE Polifemo, SEB Escar, GES Montañeiros Celtas, GE Gorfolí, CADE and collaborators) for providing the cave survey data. Topographic data for figures was provided by the Geographic National Institute (IGN) of Spain. We would like to thank Elena de la Puente for pointing to the elevated concentration of $\mathrm{Rn}$ in parts of Asturias.

\section{REFERENCES}

Acevedo, J., Fernández-Viejo, G., Llana-Fúnez, S., LópezFernández, C. \& J. Olona, 2019: Ambient noise tomography of the southern sector of the Cantabrian Mountains, NW Spain.- Geophysical Journal International, 219, 1, 479-495. https://doi.org/10.1093/ gji/ggz308

Alonso, J.L., Pulgar, J.A., García-Ramos, J.C. \& P. Barba, 1996: Tertiary basins and Alpine tectonics in the Cantabrian Mountains (NW Spain).- In: Friend, P.F. \& C.J. Dabrio (eds.) Tertiary Basins of Spain. Cambridge University Press, pp. 214-227, Cambridge. https://doi.org/10.1017/CBO9780511524851.031

Alonso, J.L., Martínez-Abad, I. \& J.C. García-Ramos, 2007: Nota sobre la presencia de una sucesión cretácica en el Macizo de Las Ubiñas (Cordillera Cantábrica). Implicaciones tectónicas y geomorfológicas.- Geogaceta, 43, 47-50.

Alonso, J.L., Marcos, A. \& A. Suárez, 2009: Paleogeographic inversion resulting from large out of se- quence breaching thrusts: The León Fault (Cantabrian Zone, NW Iberia). A new picture of the external Variscan Thrust Belt in the Ibero-Armorican Arc. - Geologica Acta, 7, 4, 451-473. https://doi. org/10.1344/105.000001449

Alvarez-Gallego, M., Garcia-Anton, E., Fernandez-Cortes, A., Cuezva, S. \& S. Sanchez-Moral, 2015: High radon levels in subterranean environments: Monitoring and technical criteria to ensure human safety (case of Castañar cave, Spain).- Journal of Environmental Radioactivity, 145, 19-29. http://dx.doi. org/10.1016/j.jenvrad.2015.03.024

Arche, A. \& J. López-Gómez, 1996: Origin of the Permian-Triassic Iberian Basin, central-eastern Spain.Tectonophysics, 266, 1-4, 443-464. https://doi. org/10.1016/S0040-1951(96)00202-8

Ballesteros, D., Cuesta, A. \& A. Rubio-Ordóñez, 2011: Actividad ígnea filoniana en los Picos de Europa (N 
de España): basaltos, lamprófidos y andesitas.- Geogaceta, 50, 1, 55-58.

Ballesteros, D., Jiménez-Sánchez, M., García-Sansegundo, J. \& M. Borreguero, 2014: SpeleoDisc: A 3-D quantitative approach to define the structural control of endokarst. An application to deep cave systems from the Picos de Europa, Spain.- Geomorphology, 216, 141-156. https://doi.org/10.1016/j. geomorph.2014.03.039

Ballesteros, D., Jiménez-Sánchez, M., Giralt, S., GarcíaSansegundo, J. \& M. Meléndez-Asensio, 2015a: A multi-method approach for speleogenetic research on alpine karst caves. Torca La Texa shaft, Picos de Europa (Spain).- Geomorphology, 247, 35-54. https://doi.org/10.1016/j.geomorph.2015.02.026

Ballesteros, D., Malard, A., Jeannin, P.-Y., JiménezSánchez, M., García-Sansegundo, J., MeléndezAsensio, M. \& G. Sendra, 2015b: KARSYS hydrogeological 3D modeling of alpine karst aquifers developed in geologically complex areas. Picos de Europa National Park.- Environmental Earth Science, 74, 7699-7714. https://doi.org/10.1007/s12665-0154712-0

Ballesteros, D., Giralt, S., García-Sansegundo, J. \& M. Jiménez-Sánchez, 2019: Quaternary regional evolution based on karst cave geomorphology in Picos de Europa (Atlantic Margin of the Iberian Peninsula).- Geomorphology, 336, 133-151. https://doi. org/10.1016/j.geomorph.2019.04.002

Barbosa, S.M., Donner, R.V. \& G. Steinitz, 2015: Radon applications in geosciences - Progress \& perspectives.- European Physical Journal: Special Topics, 224, 597-603. https://doi.org/10.1140/epjst/e201502393-y

Baskaran, M., 2016: Radon: A tracer for geological, geophysical and Geochemical studies.- Springer International Publishing, pp. 260, Berlin.

Bourges, F., Genthon, P., Genty, D., Lorblanchet, M., Mauduit, E. \& D. D'Hulst, 2014: Conservation of prehistoric caves and stability of their inner climate: Lessons from Chauvet and other French caves.- Science Total Environmental, 493, 79-91. https://doi. org/10.1016/j.scitotenv.2014.05.137

Briestensky, M., Thinova, L., Stemberk, J. \& M.D. Rowberry, 2011: The use of caves as observatories for recent geodynamic activity and radon gas concentrations in the Western Carpathians and Bohemian Massif.- Radiation Protection Dosimetry, 145, 2-3, 166-172. https://doi.org/10.1093/rpd/ncr080

Briestensky, M., Thinová, L., Praksová, R., Stemberk, J., Rowberry, M.D. \& Z. Knejflová, 2014: Radon, Carbon Dioxide and Fault Displacements in Central Europe related to the Tohoku Earthquake.- Radia- tion Protection Dosimetry, 160, 1-3, 78-82. https:// doi.org/10.1093/rpd/ncu090

Cadenas, P. \& G. Fernández-Viejo, 2017: The Asturian Basin within the North Iberian margin (Bay of Biscay): Seismic characterisation of its geometry and its Mesozoic and Cenozoic cover.- Basin Research, 29, 4, 521-541. https://doi.org/10.1111/bre.12187

Cadenas, P., Fernández-Viejo, G., Pulgar, J. A., Tugend, J., Manatschal, G. \& T.A. Minshull, 2018: Constraints Imposed by Rift Inheritance on the Compressional Reactivation of a Hyperextended Margin: Mapping Rift Domains in the North Iberian Margin and in the Cantabrian Mountains.- Tectonics, 37, 3, 758785. https://doi.org/10.1002/2016TC004454

Cepedal, A., Fuertes-Fuente, M., Martín-Izard, A., García-Nieto, J. \& M.C. Boiron, 2013: An intrusionrelated gold deposit (IRGD) in the NW of Spain, the Linares deposit: Igneous rocks, veins and related alterations, ore features and fluids involved.- Journal of Geochemical Exploration, 124, 101-126. https:// doi.org/10.1016/j.gexplo.2012.08.010

Chiodini, G., Caliro, S., Aiuppa, A., Avino, R., Granieri, D., Moretti, R. \& F. Parello, 2011: First 13C/12C isotopic characterization of volcanic plume $\mathrm{CO} 2$.- Bulletin of Volcanology, 73, 5, 531-542. http://dx.doi. org/10.1007/s00445-010-0423-2

Corretge, L.G. \& O. Suarez, 1990: Igneous Rocks.- In: Dallmeyer, R.D. \& E. Martinez Garcia (eds.) PreMesozoic Geology of Iberia. Springer Berlin Heidelberg, pp. 72-79, Berlin. https://doi.org/10.1007/9783-642-83980-1_5

DeFelipe, I., Pedreira, D., Pulgar, J.A., Iriarte, E. \& M. Mendia, 2017: Mantle exhumation and metamorphism in the Basque-Cantabrian Basin (N Spain): Stable and clumped isotope analysis in carbonates and comparison with ophicalcites in the North-Pyrenean Zone (Urdach and Lherz).- Geochemistry, Geophysics, Geosystems, 18, 2, 631-652. https://doi. org/10.1002/2016GC006690

DeFelipe, I., Pulgar, J.A. \& D. Pedreira, 2018: Crustal structure of the eastern Basque-cantabrian zone Western Pyrenees: From the Cretaceous hyperextension to the Cenozoic inversion.- Revista de la Sociedad Geológica de España, 31, 2, 69-82. https:// doi.org/10.13039/501100003329

DeFelipe, I., Pedreira, D., Pulgar, J.A., van der Beek, P.A., Bernet, M. \& R. Pik, 2019: Unraveling the Mesozoic and Cenozoic Tectonothermal Evolution of the Eastern Basque-Cantabrian Zone-Western Pyrenees by Low-Temperature Thermochronology.- Tectonics, 38, 9, 3436-3461. https://doi. org/10.1029/2019TC005532

Dueñas, C., Fernández, M.C., Cañete, S., Carretero, J. \& 
E. Liger, 1999: 222Rn concentrations, natural flow rate and the radiation exposure levels in the Nerja Cave.- Atmospheric Environment, 33, 3, 501-510. https://doi.org/10.1016/S1352-2310(98)00267-2

Dumitru, O.A., Onac, B.P. \& C. Cosma, 2016: Radon levels in caves from San Salvador, the Bahamas: a reconnaissance survey.- Carbonates and Evaporites, 31, 153-161. https://doi.org/10.1007/s13146-0150251-8

Elío, J., Crowley, Q., Scanlon, R., Hodgson, J. \& S. Long, 2017: Logistic regression model for detecting radon prone areas in Ireland.- Science of The Total Environment, 599, 1317-1329. https://doi.org/10.1016/j. scitotenv.2017.05.071

Espina, R., 1994: Extensión mesozoica y acortamiento alpino en el borde occidental de la Cuenca Vasco Cantábrica.- Cuadernos del Laboratorio Xeolóxico de Laxe, 19, 137-150.

Favre, G., 1978: Recherches Speleologiques Asturies (Espagne). Picos de Europa 1976-77-78.- Société Suisse de Spéléologie, pp. 52, La Rippe.

Fernández, F.J., Alonso, J.L. \& L. Pando, 2018: Evidencias de actividad tectónica cuaternaria en el occidente de la Zona Cantábrica (Puertos de Marabio, Manto de la Sobia).- Geogaceta, 64, 3-6.

Fernandez, P.L., Quindos, L.S., Soto, J. \& E. Villar, 1984: Radiation exposure levels in Altamira Cave.- Health Physics, 46, 2, 445-447.

Fernández, P.L., Gutierrez, I., Quindós, L.S., Soto, J. \& E. Villar, 1986: Natural ventilation of the Paintings Room in the Altamira cave.- Nature, 321, 586-588. https://doi.org/10.1038/321586a0

Fernandez-Cortes, A., Sanchez-Moral, S., Cuezva, S., Cañaveras, J.C. \& R. Abella, 2009: Annual and transient signatures of gas exchange and transport in the Castañar de Ibor cave (Spain).- International Journal of Speleology, 38, 2, 153-162. http://dx.doi. org/10.5038/1827-806X.38.2.6

Fernandez-Cortes, A., Sanchez-Moral, S., Cuezva, S., Benavente, D. \& R. Abella, 2011: Characterization of trace gases' fluctuations on a «low energy» cave (Castañar de Íbor, Spain) using techniques of entropy of curves.- International Journal of Climatology, 31, 1, 127-143. https://doi.org/10.1002/joc.2057

Fernandez-Cortes, A., Benavente, D., Cuezva, S., Cañaveras, J.C., Alvarez-Gallego, M., Garcia-Anton, E., Soler, V. \& S. Sanchez-Moral, 2013: Effect of water vapour condensation on the radon content in subsurface air in a hypogeal inactive-volcanic environment in Galdar cave, Spain.- Atmospheric Environment, 75, 15-23. https://doi.org/10.1016/j. atmosenv.2013.04.030

Fernández-Suárez, J., Gutiérrez-Alonso, G., Jenner, G.A.
\& S.E. Jackson, 1998: Geochronology and geochemistry of the Pola de Allande granitoids (northern Spain): their bearing on the Cadomian-Avalonian evolution of northwest Iberia.- Canadian Journal of Earth Sciences, 35, 1439-1453. https://doi. org/10.1139/e98-074

Fernández-Viejo, G., López-Fernández, C., DomínguezCuesta, M.J. \& P. Cadenas, 2014: How much confidence can be conferred on tectonic maps of continental shelves? The Cantabrian-Fault case.- Scientific Reports, 4, 3661. https://doi.org/10.1038/ srep03661

Fillon, C., Pedreira, D., Van Der Beek, P.A., Huismans, R.S., Barbero, L. \& J.A. Pulgar, 2016: Alpine exhumation of the central Cantabrian Mountains, Northwest Spain.- Tectonics, 35, 2, 339-356. https:// doi.org/10.1002/2015TC004050

Gallastegui, G., Cuesta, A., Suárez, O. \& A. Lobo, 2001: Granates en las rocas intrusivas calcoalcalinas ricas en $\mathrm{K}$ de la Unidad Pisuerga-Carrión (Zona Cantábrica, Norte de España).- Geogaceta, 29, 53-56.

Gallastegui, J., Pulgar, J.A. \& J. Gallart, 2016: Alpine tectonic wedging and crustal delamination in the Cantabrian Mountains (NW Spain).- Solid Earth, 7, 4, 1043-1057. http://dx.doi.org/10.5194/se-7-10432016

Garavaglia, M., Braitenberg, C. \& M. Zadro, 1998: Radon monitoring in a cave of North-Eastern Italy.- Physics and Chemistry of the Earth, 23, 9-10, 949-952. https://doi.org/10.1016/S0079-1946(98)00125-6

García-Talavera, M., García-Pérez, A., Rey, C. \& L. Ramos, 2013: Mapping radon-prone areas using $\gamma$-radiation dose rate and geological information.Journal of Radiological Protection, 33, 605-620. https://doi.org/10.1088/0952-4746/33/3/605

Ghosh, D., Deb, A., Sengupta, R., Bera, S., Sahoo, S.R., Haldar, S. \& K.K. Patra, 2011: Comparative study of seismic surveillance on radon in active and nonactive tectonic zone of West Bengal, India.- Radiation Measurements, 46, 3, 365-370. https://doi. org/10.1016/j.radmeas.2010.07.016

Gillmore, G.K., Sperrin, M., Phillips, P. \& A. Denman, 2000: Radon Hazards, Geology, and Exposure of Cave Users: A Case Study and Some Theoretical Perspectives.- Ecotoxicology and Environmental Safety, 46, 3, 279-288. https://doi.org/10.1006/ eesa.2000.1922

Gillmore, G.K., Phillips, P.S., Denman, A.R. \& D.D. Gilbertson, 2002: Radon in the Creswell Crags Permian limestone caves.- Journal of Environmental Radioactivity, 62, 2, 165-179. https://doi.org/10.1016/ S0265-931X(01)00159-X

Girault, F., Perrier, F., Gajurel, A.P., Bhattarai, M., Koira- 
la, B.P., Bollinger, L., Fort, M. \& C. France-Lanord, 2012: Effective radium concentration across the Main Central Thrust in the Nepal Himalayas.- Geochimica et Cosmochimica Acta, 98, 203-227. https://doi.org/10.1016/j.gca.2012.09.001

González-Díez, A., Soto, J., Gómez-Arozamena, J., Bonachea, J., Martínez-Díaz, J.J., Cuesta, J.A., Olague, I., Remondo, J., Fernández Maroto, G. \& J.R. Díaz de Terán, 2009: Identification of latent faults using a radon test.- Geomorphology, 110, 1-2, 11-19. https:// doi.org/10.1016/j.geomorph.2008.12.020

González Menéndez, L., Heredia, N. \& A. Marcos, 2008: Mapa Geológico Digital continuo E. 1:50.000, Zona Asturoccidental-Leonesa (Zona-1100).- In: Navas, J. (ed.) GEODE Mapa Geológico Digital continuo de España. Instituto Geológico y Minero de España, Madrid.

Gregorič, A., Vaupotič, J. \& F. Gabrovšek, 2013: Reasons for large fluctuation of radon and $\mathrm{CO} 2$ levels in a dead-end passage of a karst cave (Postojna Cave, Slovenia).- Natural Hazards and Earth System Science, 13, 2, 287-297. https://doi.org/10.5194/ nhess-13-287-2013

Grobe, R.W., Alvarez-Marrón, J., Glasmacher, U.A. \& F.M. Stuart, 2014: Mesozoic exhumation history and palaeolandscape of the Iberian Massif in eastern Galicia from apatite fission-track and $(\mathrm{U}+\mathrm{Th}) /$ He data.- International Journal of Earth Sciences, 103, 539-561. http://dx.doi.org/10.1007/s00531013-0976-3

Gunn, J., Fletcher, S. \& R. Hyland, 1991: Health implications of radon in British caves.- Environmental Geochemistry Health, 13, 149. https://doi.org/10.1007/ BF01758550

Hakl, J., Hunyadi, I., Csige, I., Géczy, G., Lénárt, L. \& A. Várhegyi, 1997: Radon transport phenomena studied in karst caves - international experiencies on radon levels and exposures.- Radiation Measurements, 28, 1-6, 675-684. https://doi.org/10.1016/ S1350-4487(97)00163-7

Hoyos, M., Cañaveras, J.C., Sánchez-Moral, S., Sanz-Rubio, E. \& V. Soler, 1998: Microclimatic characterization of a karstic cave: Human impact on microenvironmental parameters of a prehistoric rock art cave (Candamo Cave, northern Spain).- Environmental Geology, 33, 231-242. https://doi.org/10.1007/ s002540050242

Julivert, M., 1967: La Ventana del Río Monasterio y la terminación meridional del Manto del Ponga.- Trabajos de Geología, 1, 59-76.

Katsanou, K., Stratikopoulos, K., Zagana, E. \& N. Lambrakis, 2010: Radon changes along main faults in the broader Aigion Region, NW Peloponnese.- Bulletin of the Geological Society of Greece, 43, 4, 17261736. https://doi.org/10.12681/bgsg.11358

Kobal, I., Smodis, B. \& M. Skofljanec, 1986: Radon-222 air concentrations in the Slovenian Karst Caves of Yugoslavia.- Health Physics, 50, 6, 830-834.

Kobal, I., Smodis, B., Burger, J. \& M. Skofljanec, 1987: Atmospheric 222Rn in tourist caves of Slovenia, Yugoslavia.- Health Physics, 52, 4, 473-479.

Koike, K., Yoshinaga, T., Ueyama, T. \& H. Asaue, 2014: Increased radon-222 in soil gas because of cumulative seismicity at active faults.- Earth, Planets and Space, 66, 57. https://doi.org/10.1186/1880-598166-57

Kowalczk, A.J. \& P.N. Froelich, 2010: Cave air ventilation and $\mathrm{CO} 2$ outgassing by radon-222 modeling: How fast do caves breathe?.- Earth and Planetary Science Letters, 289, 1-2, 209-219. https://doi.org/10.1016/j. epsl.2009.11.010

Künze, N., Koroleva, M. \& C.D. Reuther, 2012: 222Rn activity in soil gas across selected fault segments in the Cantabrian Mountains, NW Spain.- Radiation Measurements, 47, 5, 389-399. https://doi. org/10.1016/j.radmeas.2012.02.013

L'Esperteyu Cavernícola-Espéleo Club, 1987: Avance al catálogo de cavidades del Concejo de Onís.L'Esperteyu Cavernícola-Espéleo Club, pp. 43, Gijón.

Lario, J., Sánchez-Moral, S., Cañaveras, J.C., Cuezva, S. \& V. Soler, 2005: Radon continuous monitoring in Altamira Cave (northern Spain) to assess user's annual effective dose.- Journal of Environmental Radioactivity, 80, 2, 161-174. https://doi.org/10.1016/j. jenvrad.2004.06.007

Lee, K.Y., Moon, S.H., Oh, Y.H., Ha, K. \& K.S. Ko, 2018: Determination of the radon emanation fraction from rocks by simple gamma-ray spectrometry.Journal of Radioanalytical and Nuclear Chemistry, 316, 3, 1307-1312.

Lepvrier, C. \& E. Martínez-García, 1990: Fault development and stress evolution of the post-Hercynian Asturian Basin (Asturias and Cantabria, northwestern Spain).- Tectonophysics, 184, 3-4, 345-356. https:// doi.org/10.1016/0040-1951(90)90447-G

Llana-Fúnez, S. \& C. López-Fernández, 2015: The seismogenic zone of the continental crust in Northwest Iberia and its relation to crustal structure.- Tectonics, 34, 8, 1751-1767. https://doi. org/10.1002/2015TC003877Llana-Fúnez, S. \& D. Ballesteros, 2020: Control structural del Monumento Natural de Cueva Huerta (Cordillera Cantábrica, España).- Geogaceta, 68, 7-10.

López-Fernández, C., Pulgar, J.A., Gallart, J., GonzálezCortina, J.M., Díaz, J., \& M. Ruiz, 2004: Actividad 
sísmica en el noroeste de la Península Ibérica observada por la red sísmica local del Proyecto GASPI (1999-2002).- Trabajos de Geología, 24, 91-107. https://doi.org/10.17811/tdg.24.2004.91-107

López-Fernández, C., Fernández-Viejo, G., Olona, J. \& S. Llana-Fúnez, 2018: Intraplate seismicity in northwest Iberia along the trace of the Ventaniella fault: A case of fault intersection at depth.- Bulletin of the Seismological Society of America, 108, 2, 604-618. https://doi.org/10.1785/0120170215

López-Fernández, C., Llana-Fúnez, S., Fernandez-Viejo, G., Domínguez-Cuesta, M. \& L.M. Díaz-Díaz, 2020: Comprehensive characterization of elevated coastal platforms in the North Iberian Margin: a new template to quantify uplift rates and tectonic patterns.- Geomorphology, 364, 107242. https://doi. org/10.1016/j.geomorph.2020.107242

Lu, X., Li, L.Y. \& X. Zhang, 2009: An environmental risk assessment of radon in Lantian Karst Cave of Shaanxi, China.- Water Air Soil Pollution, 198, 307316. https://doi.org/10.1007/s11270-008-9847-0

Martinez-Abad, I., Cepedal, A., Arias, D. \& A. MartinIzard, 2015: The Vilalba gold district, a new discovery in the Variscan terranes of the NW of Spain: A geologic, fluid inclusion and stable isotope study.Ore Geology Reviews, 66, 344-365. https://doi. org/10.1016/j.oregeorev.2014.10.021

Martínez-García, E., Luque, C., Burkhardt, R. \& M. Gutiérrez Claverol, 1991: Hozarco: Un ejemplo de mineralización de $\mathrm{Pb}-\mathrm{Zn}-\mathrm{Hg}$ de edad pérmica (Cordillera Cantábrica, NW de España).- Boletín de la Sociedad Española de Mineralogía, 14, 107-116.

Martínez-García, E., Antona, J., García Sánchez, A. \& J. Quiroga de la Vega, 2004: Tectonic and metallogenic significance of sedimentary manganese deposits in the Eastern Cantabrian Domain, Asturias, Northwestern Spain.- International Geology Review, 46, 3, 273-288. https://doi.org/10.2747/00206814.46.3.273

Martín-González, F., Barbero, L., Capote, R., Heredia, N. \& G. Gallastegui, 2011: Interaction of two successive Alpine deformation fronts: constraints from low-temperature thermochronology and structural mapping (NW Iberian Peninsula).- International Journal of Earth Sciences, 101, 1331-1342. https:// doi.org/10.1007/s00531-011-0712-9

Martín-Izard, A., Fuertes-Fuente, M., Cepedal, A., Moreiras, D., García-Nieto, J., Maldonado, C. \& L.R. Pevida, 2000: The Río Narcea Gold Belt intrusions: geology, petrology, geochemistry and timing.- Journal of Geochemical Exploration, 71, 2, 103-117. https://doi.org/10.1016/S0375-6742(00)00148-5

Martín-Izard, A., Gumiel, P., Arias, M., Cepedal, A.,
Fuertes-Fuente, M. \& R. Reguilón, 2009: Genesis and evolution of the structurally controlled vein mineralization $(\mathrm{Sb}-\mathrm{Hg})$ in the Escarlati deposit (León, Spain): Evidence from fault population analysis methods, fluid-inclusion research and stable isotope data.- Journal of Geochemical Exploration, 100, 1, 51-66. https://doi.org/10.1016/j.gexplo.2008.04.002

Merino-Tomé, O., Suárez Rodríguez, A., Alonso, J., González Menéndez, L., Heredia, N. \& A. Marcos, 2013: Mapa Geológico Digital continuo E. 1:50.000, Principado de Asturias (Zonas: 1100-1000-1600).In: Navas, J., (ed.) GEODE Mapa Geológico Digital continuo de España. Instituto Geológico y Minero de España, Madrid.

Morrow, C.A., Lockner, D.A., Moore, D.E. \& S. Hickman, 2014: Deep permeability of the San Andreas Fault from San Andreas Fault Observatory at Depth (SAFOD) core samples.- Journal of Structural Geology, 64, 99-114. https://doi.org/10.1016/j.jsg.2013.09.009

Nguyet, N.T.A., Duong, N.T., Schimmelmann, A. \& N. Van Huong, 2018: Human exposure to radon radiation geohazard in Rong Cave, Dong Van Karst Plateau Geopark, Vietnam.- Vietnam Journal of Earth Sciences, 40, 2, 117-125. https://doi. org/10.15625/0866-7187/40/2/11092.

Paniagua, A., Rodríguez-Pevida, L.S., Garzón, L., Pérez, J.M. \& A. Quintana, 1987: Presencia de una paragénesis Cu-Ni-Co-U-As-S en la zona cantábrica: la Mina Profunda (Cármenes, León).- Geogaceta, 2, 22-24.

Papastefanou, C., Manolopoulou, M., Stoulos, S., Ioannidou, A. \& E. Gerasopoulos, 2003: Radon concentrations and absorbed dose measurements in a Pleistocenic cave.- Journal of Radioanalytical and Nuclear Chemistry, 258, 205-208. https://doi. org/10.1023/A:1026255419731

Pedreira, D., Afonso, J. C., Pulgar, J. A., Gallastegui, J., Carballo, A., Fernàndez, M., Garcia-Castellanos, D., Jiménez-Munt, I., Semprich, J. \& O. García-Moreno, 2015: Geophysical-petrological modeling of the lithosphere beneath the Cantabrian Mountains and the North-Iberian margin: Geodynamic implications.- Lithos, 230, 46-68. https://doi.org/10.1016/j. lithos.2015.04.018

Pérez-Estaún, A., Martínez-Catalán, J.R. \& F. Bastida, 1991: Crustal thickening and deformation sequence in the footwall to the suture of the Variscan belt of northwest Spain.- Tectonophysics, 191, 3-4, 243253. https://doi.org/10.1016/0040-1951(91)90060-6

Pérez-López, R., Martín-Velázquez, S., Sánchez-Moral, S., Patyniak, M., López-Gutiérrez, J., Cuezva, S., Lario, J., Silva, P.G., Rodríguez-Pascua, M.A. \& J.L. 
Giner-Robles, 2017: New insights on speleoseismology: the geothermal gradient and heat flow values in caves for the study of active faults.- Quaternary International, 451, 165-175. https://doi.org/10.1016/j. quaint.2016.11.026

Piccini, L., 2011: Recent developments on morphometric analysis of karst caves.- Acta Carsologica, 40, 1, 4352. https://doi.org/10.3986/ac.v40i1.27

Poncela, L.Q., Navarro, P.F., Fernandez, C.S., Arozamena, J.G. \& M.B. Perez, 2004: Radon exposure in uranium mining industry vs. exposure in tourist caves.- Radiation Protection Dosimetry, 111, 1, 41-44. https:// doi.org/10.1093/rpd/nch357

Porstendörfer, J., 1994: Properties and behaviour of radon and thoron and their decay products in the air.Journal of Aerosol Science, 25, 2, 219-263. https:// doi.org/10.1016/0021-8502(94)90077-9

Puch, C., 1998: Grandes cuevas y simas de España.- Espéleo Club de Gràcia, pp. 794, Barcelona.

Pulgar, J.A., Alonso, J.L., Espina, R.G. \& J.A. Marín, 1999: La deformación alpina en el basamento varisco de la Zona Cantábrica.- Trabajos de Geología, 21, 283294. https://doi.org/10.17811/tdg.21.1999.283-295

Rodríguez-Terente, L.M., Luque Cabal, C. \& M. Gutiérrez Claverol, 2006: Los registros mineros para sustancias metálicas en Asturias.- Trabajos de Geología, 26, 19-55.

Rodríguez Fernández, L.R., López Olmedo, F., Oliveira, J.T., Medialdea, T., Terrinha, P., Matas, J., MartínSerrano, A., Martín Parra, L.M., Rubio, F., Marín, C., Montes, M. \& F. Nozal, 2015: Mapa Geológico de España y Portugal a escala 1:1.000.000.- Madrid.

Sainz, C., Quindós, L.S., Fuente, I., Nicolás, J. \& L. Quindós, 2007: Analysis of the main factors affecting the evaluation of the radon dose in workplaces: the case of tourist caves.- Journal of Hazardous Materials, 145, 3, 368-371. https://doi.org/10.1016/j. jhazmat.2006.11.033

Sainz Fernández, C., Quindós Poncela, L.S., Fernández Villar, A., Fuente Merino, I., Gutierrez-Villanueva, J.L., Celaya González, S., Quindós López, L., Quindós López, J., Fernández, E., Remondo Tejerina, J., Martín Matarranz, J.L. \& M. García Talavera, 2017: Spanish experience on the design of radon surveys based on the use of geogenic information.Journal of Environmental Radioactivity, 166, 2, 390397. https://doi.org/10.1016/j.jenvrad.2016.07.007

Sakoda, A., Nishiyama, Y., Hanamoto, K., Ishimori, Y., Yamamoto, Y., Kataoka, T., Kawabe, A. \& K. Yamaoka, 2010: Differences of natural radioactivity and radon emanation fraction among constituent minerals of rock or soil.- Applied Radiation and Iso- topes, 68, 6, 1180-1184. https://doi.org/10.1016/j. apradiso.2009.12.036

Santanach, P., Ferrús, B., Cabrera L. \& Sáez, A. (2005): Origin of a restraining bend in an evolving strikeslip system: The Cenozoic As Pontes basin (NW Spain).- Geologica Acta, 3, 225-239. https://doi. org/10.1344/105.000001393

Sciarra, A., Fascetti, A., Moretti, A., Cantucci, B., Pizzino, L., Lombardi, S. \& I. Guerra, 2015: Geochemical and radiometric profiles through an active fault in the Sila Massif (Calabria, Italy).- Journal of Geochemical Exploration, 148, 128-137. https://doi. org/10.1016/j.gexplo.2014.08.015

Sibson, R.H., 1992: Implications of fault-valve behaviour for rupture nucleation and recurrence.- Tectonophysics, 18, 1-4, 1031-1042. https://doi. org/10.1016/0040-1951(92)90065-E

Sibson, R.H., 1996: Structural permeability of fluid-driven fault-fracture meshes.- Journal of Structural Geology, 18, 8, 1031-1042. https://doi.org/10.1016/01918141(96)00032-6

Smeraglia, L., Berra, F., Billi, A., Boschi, C., Carminati, E. \& C. Doglioni, 2016: Origin and role of fluids involved in the seismic cycle of extensional faults in carbonate rocks.- Earth Planetary Science Letters, 450, 292-305. https://doi.org/10.1016/j. epsl.2016.06.042

Smith, M.E., Dumitru, O.A., Burghele, B.D., Cucos, A. \& B.P. Onac, 2019: Radon concentration in three Florida caves: Florida, Jennings, and Ocala.- Carbonates Evaporites, 34, 433-439. https://doi.org/10.1007/ s13146-018-0473-7

Somlai, J., Hakl, J., Kávási, N., Szeiler, G., Szabó, P. \& T. Kovács, 2011: Annual average radon concentration in the show caves of Hungary.- Journal of Radioanalytical and Nuclear Chemistry, 287, 427-433. https:// doi.org/10.1007/s10967-010-0841-9

Srivastava, S.P., Roest, W.R., Kovacs, L.C., Oakey, G., Levesque, S., Verhoef, J. \& R. Macnab, 1990: Motion of Iberia since the late Jurassic - Results from detailed aeromagnetic measurements in the Newfoundland basin.- Tectonophysics, 184, 3-4, 229260. https://doi.org/10.1016/0040-1951(90)90442-B

Steinitz, G., Begin, Z.B. \& N. Gazit-Yaari, 2003: Statistically significant relation between radon flux and weak earthquakes in the Dead Sea rift valley.- Geology, 31, 6, 505-508. https://doi.org/10.1130/00917613(2003)031<0505:SSRBRF > 2.0.CO;2

Suárez, O., Cuesta, A., Gallastegui, G. \& L.G. Corretge, 1993: Mineralogía y petrología de las rocas plutónicas de Infiesto (Zona Cantábrica, $\mathrm{N}$ de España).Trabajos de Geología, 19, 123-153.

Suárez, O., Gallastegui, G., Cuesta, A. \& L.G. Corretgé, 
1999: Filiación geoquímica mantélica de las rocas ígneas de Salas-Belmonte: Implicaciones petrogenéticas (Zona Cantábrica, Macizo Ibérico).- Trabajos de Geología, 21, 363-376.

Šebela, S., Vaupotič, J., Košták, B. \& J. Stemberk, 2010: Direct measurement of present-day tectonic movement and associated radon flux in Postojna Cave, Slovenia.- Journal of Cave and Karst Studies, 72, 1, 21-34. https://doi.org/10.4311/jcks2009es0077

Tavani, S., 2012: Plate kinematics in the Cantabrian domain of the Pyrenean orogen.- Solid Earth, 3, 2, 265-292. https://doi.org/10.5194/se-3-265-2012

Teixell, A., Labaume, P., Ayarza, P., Espurt, N., de Saint Blanquat, M. \& Y. Lagabrielle, 2018: Crustal structure and evolution of the Pyrenean-Cantabrian belt: A review and new interpretations from recent concepts and data.- Tectonophysics, 724-725, 146-170. https://doi.org/10.1016/j.tecto.2018.01.009

Tugend, J., Manatschal, G. \& N.J. Kusznir, 2015: Spatial and temporal evolution of hyperextended rift systems: Implication for the nature, kinematics, and timing of the Iberian- European plate boundary.- Geology, 43, 1, 15-18. https://doi.org/10.1130/ G36072.1
Vaupotič, J., 2010: Radon Levels in Karst Caves in Slovenia.- Acta Carstologica, 39, 3, 503-512. https://doi. org/10.3986/ac.v39i3.80

Wang, Y., Luo, W., Zeng, G., Wang, Y., Yang, H., Wang, M., Zhang, L., Cai, X., Chen, J., Cheng, A. \& S. Wang, 2019: High 222Rn concentrations and dynamics in Shawan Cave, southwest China.- Journal of Environmental Radioactivity, 199-200, 16-24. https://doi.org/10.1016/j.jenvrad.2018.12.029

Woith, H., 2015: Radon earthquake precursor: A short review.- European Physical Journal: Special Topics, 224, 611-627. https://doi.org/10.1140/epjst/e201502395-9

Xie, D., Liao, M. \& K.J. Kearfott, 2015: Influence of environmental factors on indoor radon concentration levels in the basement and ground floor of a building - A case study.- Radiation Measurements, 82, 52-58. https://doi.org/10.1016/j.radmeas.2015.08.008

Zarroca, M., Linares, R., Bach, J., Roqué, C., Moreno, V., Font, L. \& C. Baixeras, 2012: Integrated geophysics and soil gas profiles as a tool to characterize active faults: The Amer fault example (Pyrenees, NE Spain).- Environmental Earth Sciences, 67, 889910. https://doi.org/10.1007/s12665-012-1537-y 